\title{
Drug Allergic Reactions: Current Views (Review)
}

\author{
DOI: 10.17691/stm2016.8.1.22 \\ Received May 20, 2015
}

T.I. Eliseeva, MD, PhD, Associate Professor, Department of Children Diseases ${ }^{1}$;

I.I. Balabolkin, MD, DSc, Professor, Corresponding Member of Russian Academy of Sciences,

Chief Researcher, Department of Pulmonology and Allergology²

${ }^{1}$ Institute of Federal Security Service of Russian Federation, 2 Kazanskoe Shosse, Nizhny Novgorod, 603163,

Russian Federation;

${ }^{2}$ Scientific Children Health Centre of the Russian Academy of Sciences, 2 Lomonosovsky Avenue, Moscow, 119991,

Russian Federation

More than $7 \%$ of population suffer from drug allergy. Cases of heavy life-threatening allergic reactions are well known. In this review current considerations of mechanisms of drug immune hypersensitivity development are presented, the main clinical forms and methods of diagnosing drug allergy are described. Drug allergy is diagnosed with specific in vivo tests (skin prick test, intradermal test, patch test, provocation tests) and in vitro tests (determination of specific IgE to medications, test for basophil activation, reactions of leucocyte blast transformation, quantitative determination of cytokines and other proteins, e.g. granzyme and tryptase in peripheral blood). However, not all of these methods are available in real clinical practice, the list of commercial kits for diagnosis of drug allergy is limited. Therefore, it is especially important in patient management to rely on history-taking and general clinical examination data, to consider the available information on association of drug allergy and infections caused by viruses of herpes-group, especially in children population, on hereditary predisposition to some kinds of drug allergy.

Key words: drug allergy; diagnosing drug allergy; drug hypersensitivity reactions.

Drug allergy is characterized by hypersensitivity reactions to pharmacological agents, having an immune mechanism of development. In these reactions antibody and/or activated $T$ cells are directed against medications or their metabolites [1]. This problem is rather urgent for practical healthcare, as over $7 \%$ of people suffer from drug allergy. Moreover, heavy life-threatening allergic reactions may develop demanding hospitalization and long-term treatment [1-4]. Immunologic reactions to drugs (reactions of drug hypersensitivity) are considered among unfavorable reactions to drugs, category $\mathrm{B}$, whose mechanism is associated with abnormal response to medications (Table 1). This distinguishes them from type A reactions, which may be in any patient, and, as a rule, are connected with the main mechanism of drug effect and its dosage $[5,6]$.

Theoretically allergic reactions may be induced by all medicines, however the most common cause of them are antibiotics, unticonvulsant preparations, nonsteroidal anti-inflammatory drugs (NSAID), anesthetics. The risk of drug allergy, its clinical characteristics depend on individual properties of the immune system, drug dose, treatment duration, the route of administration, patient's sex, and also on the unique HLA-signs, which are described in increasing frequency.

Immune and nonimmune (pseudoallergic) forms of hypersensitivity reactions can develop to the medicinal preparations, often having identical clinical

Table 1

Types of unfavorable reactions to medications (According to Doña, 2014, with alterations) [5, 6]

\begin{tabular}{lc}
\hline \multicolumn{1}{c}{ Unfavorable reactions to medications } \\
\multicolumn{1}{c}{ Type A, attributed } & \multicolumn{1}{c}{ Type B, not attributed } \\
to pharmacological action & to pharmacological action \\
\hline Drug toxicity & Drug intolerance \\
Side effects & Idiosyncrasy \\
Secondary effects & Hypersensitivity reactions: \\
Drug interaction & immune \\
& a) IgE-mediated; \\
& b) T cell-mediated \\
& nonimmune reactions - \\
& of various genesis \\
\hline
\end{tabular}

For contacts: Tatyana I. Eliseyeva, e-mail: eliseevati@yandex.ru 
manifestations [3, 7]. Nonimmune variants of side-effects to the drugs may have various genesis, for example, nonspecific degranulation of mast cells or basophils with histamine release (radiocontrast agents, vancomycin), change of the arachidonic acid metabolism (NSAID), pharmacological action of the substances, causing bronchospasm (beta-blockers) [8-12].

Drug hypersensitivity reactions are divided into immediate and delayed depending on the time of their manifestation after starting the treatment [1]. Immediate drug hypersensitivity reactions develop mainly within an hour (the first six hours) after medication intake and are predominantly induced by lgE-mediated mechanism [13, 14]. Their typical symptoms are urticaria, angioneurotic edema, rhinoconjuctivitis, bronchospasm, nausea, vomiting, diarrhea, pain in the abdomen, anaphylaxia. Delayed allergic reactions may be realized at any time an hour after the drug introduction, but usually occur 6-72 $\mathrm{h}$ after the medication intake and are connected mainly with a $\mathrm{T}$ cell mechanism of allergic reaction [1, 15-18]. Their clinical manifestations are diverse and may include maculopapular exanthema, exfoliative dermatitis, erythrodermia, DRESS-syndrome (drugrelated eosinophilia with systemic symptoms), toxic epidermal necrolysis, and other bulleos reactions. General systemic effects may comprise development of hepatitis, nephritis, cytopenia, etc. [19].

\section{Pathogenetic mechanism of drug allergy development}

Drug hypersensitivity reactions have been exisiting as long as medications themselves [15]. Nevertheless, many mechanisms of their formation are not disclosed as yet and until now there are no approved diagnostic procedures for a great number of drug reactions $[6,20]$. Medications are capable to cause the development of all types of immunopathologic reactions, described by Gell and Coombs [21], but IgE-mediated and T lymphocytesmediated reactions are the most common of them [1, 22] (Table 2).

Hyperproduction of $\lg E$ antibodies by antigenspecific B lymphocytes underlies immediate allergic drug hypersensitivity reactions. Binding of specific IgE antibodies to highly affinic receptors on the surface of mast cells and basophils, their interaction with the drug antigen results in the release of preformed mediators (histamine, tryptase), tumor necrosis factor and newly formed mediators (leukotriens, prostaglandins, kinins, cytokines) $[23,24]$. These mediators can be used as diagnostic biomarkers of drug hypersensitivity. Clinically these reactions manifest with urticaria, angioedema, rhinitis, conjunctivitis, bronchspasm, gastrointestinal disorders or anaphylaxia, anaphylactic shock [25, 26]. Their development may be observed in application of foreign sera, beta-lactam antibiotics, sulphanilamides, analgizing agents, NSAIDs [24].

The second type of drug allergic reactions is cytotoxic. In this type of reaction IgG or IgM interacts with the antigen fixed to the cell membranes, causing their damage mediated by a complement [27]. Clinically it mainly manifests with immunopathological reactions of blood cells, e.g. immune hemolytic anemia [28].

The emergence of some clinical forms of drug allergy may be caused by immune comlex reactions (type III, according to Gell and Coombs classification system). The basis of them is formation of immune complexes, their deposition in the vascular bed on the endothelial membranes of the small-calibre vessels with the consequent tissue damage and microcirculation

Table 2

Drug allergy classification $[1,19,22]$

\begin{tabular}{|c|c|c|c|c|}
\hline $\begin{array}{l}\text { Reaction } \\
\text { type }\end{array}$ & $\begin{array}{l}\text { Type of immune } \\
\text { response }\end{array}$ & $\begin{array}{l}\text { Patophysiological } \\
\text { mechanisms }\end{array}$ & Clinical symptoms & Typical reaction chronology \\
\hline I & $\lg E$ & $\begin{array}{l}\text { Degranulation of mast cells } \\
\text { and basophils }\end{array}$ & $\begin{array}{l}\text { Anaphylactic shock, angioedema, } \\
\text { urticaria, bronchospasm }\end{array}$ & Within $6 \mathrm{~h}$ after the last medication intake \\
\hline II & $\lg G$ & $\begin{array}{l}\text { IgG- and complement- } \\
\text { dependent cytotoxicity }\end{array}$ & Cytopenia & Days $5-15$ after starting the medication \\
\hline III & $\begin{array}{l}\lg \mathrm{M} \text { or } \lg \mathrm{G} \text { and } \\
\text { complement }\end{array}$ & $\begin{array}{l}\text { Deposition of immune } \\
\text { complexes }\end{array}$ & $\begin{array}{l}\text { Serum sickness, urticaria, } \\
\text { vasculitis }\end{array}$ & $\begin{array}{l}\text { Days } 7-8 \text { for serum disease and urticaria, } \\
\text { days } 7-21 \text { for vasculitis after drug exposure }\end{array}$ \\
\hline IVa & $\begin{array}{l}\text { Th1 (IFN- } \gamma \\
\text { IFN- } \alpha)\end{array}$ & $\begin{array}{l}\text { Inflammation induced by } \\
\text { monocytes }\end{array}$ & Eczema & Days 1-21 after starting the medication \\
\hline $\mathrm{IVb}$ & $\begin{array}{l}\text { Th2 (IL-5, IL- } \\
4 / I L-13)\end{array}$ & Eosinophilic inflammation & Maculopapular exanthema & $\begin{array}{l}\text { From } 1 \text { to several days after starting the } \\
\text { medication for fixed dermatitis }\end{array}$ \\
\hline IVc & $\begin{array}{l}\text { Cytotoxic cells } \\
\text { (perforin, } \\
\text { granzim B) }\end{array}$ & $\begin{array}{l}\text { Keratinocyte apoptosis } \\
\text { mediated by CD4 or CD8 }\end{array}$ & $\begin{array}{l}\text { Maculopapular exanthema, fixed } \\
\text { dermatitis, Stevens-Johnson } \\
\text { syndrome, pustular exanthema }\end{array}$ & $\begin{array}{l}\text { Days } 1-2 \text { after starting the medication } \\
\text { for fixed dermatitis } \\
\text { Days } 4-28 \text { after starting the medication } \\
\text { for Stevens-Johnson syndrome }\end{array}$ \\
\hline IVd & $\begin{array}{l}\text { T cells (IL-8/ } \\
\text { CXCL-8, IL-17) }\end{array}$ & Neutrophilic inflammation & $\begin{array}{l}\text { Acute generalized } \\
\text { exanthematous pustulosis }\end{array}$ & $\begin{array}{l}\text { Days 1-2 after drug exposure (more delayed } \\
\text { terms are possible) }\end{array}$ \\
\hline
\end{tabular}


disorders [27, 29]. Immune complex reactions run with the involvement of a compliment into the pathological process, and anaphylotoxins $\mathrm{C} 3 \mathrm{a}$ and $\mathrm{C} 5 \mathrm{a}$ produced in this process cause histamine, proteolytic enzymes and vasoactive amines to be released from the mast cells and basophils. This mechanism is the leading one in the development of serum sickness, vasculitis, systemic lupus erythematosus, Arthus phenomenon, some exanthemas of drug origin [29, 30]. The most frequent reason of immune complex variant of drug allergy is application of antibiotics, sera, vaccines, sulphanilamides, anesthetics, NSAIDs, new immunobiologic preparations (based on monoclonal antibodies) [29-32].

However, in recent years special attention has been drawn to delayed allergic reactions to medications, which are mediated by $\mathrm{T}$ lymphocytes. The most common target for $\mathrm{T}$ lymphocytes responding to medications is skin, but other organs may also be involved in the process. First, processing of drug antigen by dendrite cells if performed, then antigen is transported to the regional lymph nodes, where it is presented by $T$ cells. Later antigen-specific $T$ lymocytes migrate to the targeted organ, and after antigen exposure they are activated and secrete proinflammatory cytokines, which cause inflammation and damage of the tissue [23]. Clinically delayed drug hypersensitivity reactions manifest with dermatologic symptoms: itching maculopapulous rash, fixed drug rashes, vasculitis, toxic epidermal necrolysis, Stevens-Johnson syndrome, generalized bullous fixed drug rashes, acute generalized exanthematous pustulosis and symmetric drug-related intertrigous exanthemas, located on extensor surfaces of the limbs [33, 34]. Internal organs can also be affected by the pathological process (isolated or in combination with dermatologic symptoms resulting in hepatitis, kidney damage, hypersensitivity pneumonitis, cytopenia $[35,36]$.

It has been also noted, that one and the same patient can develop several types of immunologic reactions to pharmacological preparations. Thus, it is proved, that both IgE-mediated and cell-mediated reactions participate in the development of allergy to insulin [37-39].

Numerous medications and/or their metabolites are haptens, but binding to proteins, they form full antigen. Such newly formed antigens can induce both $\lg E$ and $T$ cell-mediated drug hypersensitivity reactions [15, 40].

Of great interest are current investigations, demonstrating obvious relation of genetic factors with the risk of developing immediate and delayed allergic drug reactions [15, 41, 42]. It is testified, in particular, by the revealed interrelations between the StevensJohnson syndrome, epidermal toxic necrolysis, induced by carbamazepine and HLA-B*1502 [43], and also by association of IL-4 and IL-10 gene polymorphisms with immediate drug hypersensitivity reactions to beta-lactam antibiotics [44].

Viral infections, including herpesviruses, as have been estimated in recent years, can provoke drug hypersensitivity reaction and skin rashes, if a drug (usually antibiotics) is used in the period of infectious process. Clinical manifestations may be rather serious - in the form of DRESS-syndrome and other systemic manifestations [15, 45-48].

Hypersensitivity reactions to medications occur more commonly in patients, including children, suffering from allergic diseases. It is likely to be connected with the changes of metabolic body functions in biotransformation of medicinal compounds and, in particular, with changes in their acetylation activity, formation of antigen determinants while interacting with the body proteins [49].

\section{Clinical manifestations of drug hypersensitivity}

As shown above, clinical manifestations of drug hypersensitivity can be immediate and delayed relative to the time of starting the medication. Additionally, systemic (anaphylaxia, drug fever, serum sickness) and organospecific variants of drug allergic reactions are distinguished. In current publications, skin is considered to be the main target organ in drug hypersensitivity, though other organs can be involved in the pathological process: hemopoiesis system (eosinophilia, cytopenia, hemolytic anemia), respiratory system (rhinitis, bronchospasm, laryngeal edema, pulmonary eosinophilic infiltrate), urinary system (glomerulonephritis, nephritic syndrome, interstitial nephritis), hepatobilliar system (hepatocellular lesions, cholestasis) [16, 36, 50].

The main syndromes characteristic of drug hypersensitivity, including those described recently, are considered below.

Skin lesions in drug allergy. Dermatologic symptoms are the most frequent in drug allergy, due to a high immune activity of the skin [51-53]. Rashes are of polymorphic character. They are accompanied by itching, which is most intensive in measles-like or scarlatiniform rash [52].

Maculopapulous rash. Papulous and/or measleslike rash compose $75-90 \%$ of drug-induced skin eruptions [54].

The onset of rash is observed, as a rule, 1 week after medication exposure [55]. They are not usually dangerous, if there are no other manifestations. Cytotoxic CD4+ ${ }^{+} \mathrm{T}$ cells are the prevailing type of cells in this case [22]. However, progression of eruptions to more serious manifestations, including toxic epidermal necrolisis, which is mainly mediated by $\mathrm{CD}^{+}$cytotoxic T cells, is possible $[51,56]$. These cutaneous changes mostly disappear some days after the preparation is discontinued, which is often accompanied by peeling of epidermis, leaving areas of discoloration. The main difficulty of clinical diagnosis of these pathological conditions is to differentiate them from infectious exanthems. Some clinical variants of drug hypersensitivity are realized in a certain combination of infectious agents and medications. An example is the risk of exanthema occurrence in using antibacterial 
preparations of aminopenicillin group in patients with infection, caused by Epstein-Barr virus [46, 47].

Urticaria. It is considered at present as a rather typical variant of drug rashes, but it occurs not so often as maculopapulous rash. Urticaria presents itching blisters of various size and localization, completely disappearing during 24 (48) h, sometimes associated with Quincke's edema. Blisters usually appear relatively quickly - from several minutes to several hours after starting the preparation, may be a component of anaphylactic reactions, includinf fatal ones. In some patients drug urticaria is based on IgE-mediated allergic reactions [52]. Though in the majority of cases of drug hypersensitivity pseudoallergic urticaria variants are observed, which may be caused by NSAIDs, angiotensin converting enzyme inhibitors and other medications [57]. In individuals, suffering from chronic urticaria, allergy to NSAIDs is noted in $30 \%$ of cases.

Angioedema of drug etiology is clinically characterized by rapid development in the area of lips, eyelids, sometimes auricle, a dorsal surface of the hands and feet, and in the region of genitals [58].

Fixed dermatitis is an interesting type of drug rash, consisting of one or several elements (erymatous, bullous, in the form of plates), of various shapes and sizes, with distiguished boundaries. They are established to occur in one and the same place each time the preparation is introduced [59]. Discontinuance of the medicine is usually accompanied by reduction of symptoms but often with retained hyperpigmentation, which allows easy determination of the affected area. If the drug is introduced a second time, symptoms recur within $2 \mathrm{~h}$, the number of elements often increases. This clinical variant is usually associated with $\mathrm{CD}^{+} \mathrm{T}$ cells [60]. When the area of skin involvement is not large, the course is likely to be favorable, but in the extensive process with the systemic symptoms in the form of fever and arthralgia the prognosis may be not so optimistic and differential diagnosis includes Stevens-Johnson syndrome [59].

Acute generalized exanthematous pustulosis (AGEP) is one of the most serious forms of drug allergy described in recent years. This pathologic condition often comprises acute fever (over $38^{\circ} \mathrm{C}$ ) and skin eruptions in the form of small pustules within the areas of erythema arising within several hours after starting the causative medication [61]. Mucous membranes may be involved in the process in $25 \%$ of cases, but the course may remain favorable enough. Characteristic for this condition are neutrophilosis, moderate eosiniphilia. In some cases edema of the face and arms is observed, but in general inner organs are rarely affected. The pharmaceuticals usually causing AGEP syndrome include beta-lactams, NSAIDs, chinolones, macrolides, calcium channel blockers, and also antimalarial drugs, such as chloroquine. No evident genetic markers associated with AGEP have been found [62].

Drug-induced hypersensitivity syndrome (DHS or DiHS) and DRESS-syndrome. These syndromes represent reactions to medications, accompanied by eosinophilia and systemic symptoms potentially threatening the life. They were first described not long ago, when anticonvulsunt preparations were used [63]. Clinical characteristics include acute onset, rash, fever, and at least one of the syndromes (lymphadenitis, hepatitis, nephritis, pneumonia, thyroiditis) in combination with hematologic impairments (eosinophilia, atypical lymphocytes, thrombocytopenia, leucopenia) [64]. However, rash may not be always present, its character may be significantly different in various patients. Mortality rate may reach $10 \%$, more often from hepatic insufficiency. Usualy symptoms appear 2-6 weeks after starting the offending medication, which is an important diagnostic criterion [65]. Symptoms may last for weeks and months after the causative agent is discarded. The most common preparations associated with DRESS/ DiHS are found to be carbamazepine and other aromatic anticonvulsants, sulphanilamides, allopurinol, a number of drugs against HIV. The mechanism of syndrome development is referred to reactions of $\mathrm{IVb}$ type. An important role in the development of this syndrome is given to reactivation of herpesvirus 6, and other herpesvirus infections (Epstein-Barr virus, cytomegalovirus, herpesvirus 7) [66].

Exudative erythema multiforme ischaracterized by polymorphic eruptions in the form of erythema, targe-shaped papules, which can progress to vesiculous and bullous lesions and form erosions at their sites [67]. Eruptions are mainly distributed acrally: on the hands, feet, upper and lower limbs. Mucous membranes may also be affected. Erythema multiforme is a polyetiological disease, with underlying reactions of hypersensitivity to drugs or infections, but in some cases it is associated with other pathological conditions, e.g. Kawasaki disease [68]. Treatment of the patients is based on stopping the offending drugs or treating the existing infectious illnesses. In some cases treatment is recurrent due to unremoved antigen stimulation [69, 70].

Stivens-Johnson syndrome is considered by many specialists as a heavy form of exudative erythema multiforme, in which a large skin area is involved in the pathological process presenting polymorphic eruptions including formation of bulls, ulcerations, lesions of mucous membranes, visceral organs, fever, marked malaise [70, 71]. Other investigators [72, 73] consider this syndrome as an independent disease close in its genesis to the syndrome of toxic epidermal necrolysis. Both syndromes are thought to be the forms of abnormal necrotic reactions of the skin and mucous membranes to medicaments and/or infections, accompanied by epidermis and epithelium detachment. Historically they were classified as forms of exudative erythema multiforme, but at present they are considered as different diseases [72, 73].

Toxic epidermal necrolysis is a heavy variant of drug allergy running with bulleous skin damage, mortality rate reaching 30\% [74]. Some authors $[53,71]$ regard Stevens-Johnson syndrome as its milder form. The differences are in the area of skin lesions and in the 
character of cutaneous alterations. The onset is noted to have a sudden rise of temperature, malaise with subsequent eruptions, which are painful to touch. Then blisters start forming, a classic Nikolsky's sign appears, when a slight lateral pressure results in epidermis rejection. Histologically it corresponds to keratinocyte apaptose with separation between the derma and epidermis. Mucous membranes of the mouth and reproductive organs are being involved in the process as well as that of intestine and eyes, leading sometimes to blindness [75]. These reactions are immune-mediated and HLA-associations with certain medications are described [62]. Skin manifestations are mainly caused by cytotoxic $T$ cells but other cells can play an important role in ithe formation of this syndrome [76]. Granulysin, tumor necrosis factor and some other molecules play a special role among the basic molecules, which mediate toxic damage of keratinocytes both in this syndrome and Stevens-Johnson syndrome. Their identification is used as diagnostic tests, when managing patients with these diseases [77-79].

In addition to the skin lesion variants, described above, other skin reactions to the drugs are possible:

photodermatitis - erymatous eruptions on the open body parts, formation of vesicles, bulls is also possible [80];

Arthus-Sakharov phenomenon - local allergic reaction in the form of infiltrate, abscess;

erythema nodosum - hypodermic nodes of the red color, localizing mainly on the anterior surface of both shins, may be followed by subfibrility, malaise, arthralgias and myalgias;

allergic vasculitis - symmetric eruptions, leaving long-term pigmentation, localizing usually in the lower third of the shins, ankles, buttocks;

contact allergic dermatitis - appearance of erythema and edema at the site of medication exposure, vesicles and bulls are also possible [51].

\section{Systemic and organ damages in drug allergy}

As indicated above, despite the fact, that the skin is the major target organ in drug allergy, other organs can also be involved in the pathologic process, and systemic effects are possible as well.

Anaphilaxia is a serious, life-threatening, generalized or systemic reaction of hypersensitivity. Conditions with a similar clinical picture, called nonallergic anaphlaxia, may occur in clinical practice. Anaphylactic shock refers to the heaviest life-threatening manifestations of anaphylaxia to the allergen contact (medication), followed by marked hemodynamic disorders resulting in circulation insufficiency and hypoxia of all vital organs. High lethality rate has been noted [81-83].

Serum sickness is an acute allergic reaction developing according to immune complex mechanism as a response to the introduction of heterologous sera, beta-lactam antibiotics, sulphanilamides, cytostatics, NSAIDs, monoclonal antibodies [27, 30, 31]. Symptoms appear 1-3 weeks after drug exposure as eruptions (urticaria, maculopapular rash), fever, arthralgia (mainly of the large joints), lymphodenopathy. Disease duration is from several days to several weeks depending on its severity.

Drug-induced fever may be provoked by application of beta-lactam antibiotics or other antimicrobial agents and have manifestations as in drug allergy $[84,85]$. It is characterized by a rise of body temperature from subfebrile values to $39^{\circ} \mathrm{C}$, may last for a short or long time. The mechanism of its development is immune complex or cell mediated. In contrast to other fevers, the patient feels rather well. The fever subsides 2-3 days after the offending medication is discontinued. If the preparation is administered a second time, it recurs several hours later [85].

\section{Manifestations of drug allergic reactions in children}

The majority of allergic reactions to drugs in children are connected with administration of beta-lactam antibiotics, NSAIDs occupy the second place, and then in the decreasing order are macrolide antibiotics, sulphanilamides, anticonvulsant drugs, radiocontrast substances, chemiotherapy preparations and other medications [86]. The risk factors of forming drug allergy in children are acute respiratory viral infections, especially in those predisposed to allergy, herpesvirus infections [46, 87, 88]. Atopia, bronchial asthma, urticaria, atopic dermatitis are significant risk factors for formation of children drug allergy [86]. The main difficulty in its diagnosis is differentiation of papuar/measleslike rash with possible viral exanthemas, which are very often observed in this age group [86]. Differential diagnosis is frequently very complicated, it is necessary to estimate the temporal relationship between drug intake and the reaction onset; it is important to consider the condition of the skin, mucous membranes, presence of fever, lymphodenopathy, changes in laboratory tests (eosinophilia of the peripheral blood, increase of hepatic transaminases level).

In the current literature it is recognized, that the main clinical manifestations of drug hypersensitivity in children are diverse skin rashes and urticaria [56]. Other manifestations are mentioned not so often: allergic rhinitis, angioedema, attacks of bronchial asthma, stomatitis, hemorrhagic vasculitis, enteritis, fever, anaphylactic shock, Stevens-Johnson syndrome, Lyell's syndrome [86, 89-91].

Predominant symptoms of drug hypersensitivity in children with bronchial asthma, atopic dermatitis or dermato-respiratory syndrome are diverse. In children with bronchial asthma the most common manifestations of drug allergy are bronchial asthma attacks (35.6\%), the second place is given to urticaria $(28.6 \%)$; in $19.5 \%$ of children allergy manifests with various exanthemas, in $11.7 \%$ of patients in the form of angioedema [49]. In children suffering from atopic dermatitis drug allergy manifests often with exacerbation of atopic dermatitis $(44.8 \%)$, urticaria and angioedema, occurring with equal 
incidence, take the second place $(10 \%)$, exanthemas are noted in $16.8 \%$ of patients with this disease [49]. In children with combined manifestation of skin and respiratory allergy drug hypersensitivity reactions most commonly manifest with acute atopic dermatitis (37.5\%), angioedema $(22.5 \%)$, rarer with bronchial asthma attacks (17.5\%) and urticaria (15.6\%) $[16,49,86]$.

\section{Current approaches to drug allergy diagnosis}

The existing scientific data do not allow formation of comprehensive complex of measures on diagnosing drug allergy. In this connection, methods of general clinical diagnosis continue to be of determining value, especially history-taking (allergologic, pharmacologic and family history), general clinical examination with revealing the main syndromes typical of drug allergy. To diagnose some clinical and pathogenetic variants of drug allergy, in vivo testing and some biological in vitro testing can be performed [92, 93]. However, the list of certified methods of drug allergy investigation available for practical use is rather scanty. The majority of methods remained within the frames of study projects.

Thoroughly performed history-taking is of principale importance in the diagnosis of drug allergy [93]. The list of questions may be considered classic: to establish the sequence of symptom occurrence, their duration and connection with the intake of medications to which hypersensitivity reactions seem to develop; to determine the time interval between the onset of the reaction and the last dose of the drug, the influence of treatment discontinuance on symptom dynamics, as wll as the results of using in the past other medicines of the same class [1, 49]. Of great importance are data on allergic reactions and diseases in the patient's relatives, including reactions to medications. Allergologic and pharmacologic history gives grounds to suspect in a patient the development of drug allergy or its rejection with a great deal of confidence. It should be taken into consideration, that $1-10 \%$ of people with drug allergy have a syndrome of multiple drug intolerance (intolerance to three and more drugs, which are not connected either structurally or pharmacologically) [94-99].

As to the instrumental and laboratory methods of investigation in drug allergy, it is underlined in the majority of the current published reports, that their choice is determined by the specificity of clinical manifestations, intensity of systemic and organspecific symptoms, the supposed mechanism of drug hypersensitivity reaction. In this connection, hemogram, radiological lung examination, investigation of hepatic and renal functions, determining antinuclear and anticytoplasmatic antibodies, specific immunological tests, and in some cases tissue biopsy are included in the list of diagnostic methods [93]. Thorough clinical examination of patients with drug hypersensitivity allows evaluation of the character, severity and danger of symptoms and conduction of the adequate laboratory study [100]. Such approach helps in the majority of cases to make a correct diagnosis. In the acute phase of hypersensitivity reaction it facilitates to make a decision to stop or continue the treatment, which might have provoked formation of drug hypersensitivity reaction. If there exists the danger of patient's condition worsening, the suspected drugs should be discarded.

Identification of offending antigen and biomarkers typical of certain hypersensitivity reaction are of substantial help in diagnosis of drug allergy course additionally to medical history and clinical data. Over the last years intensive studies are being carried on in this direction [1, 93]. Allergological diagnosis can be conducted using in vivo and in vitro methods.

In vivo methods (skin tests, provoking tests) are usually economically affordable and clinically informative. However, these tests can be performed only 4-6 weeks after stopping drug hypersensitivity reaction, and require observation of special conditions. This reduces their value as they cannot be applied for emergency diagnosis and therapy (post-factum diagnosis).

When it is impossible to exclude the diagnosis of drug allergy on the basis of medical history and clinical data, specific allergological diagnosis should be carried out in specialized centers. It will assist in establishing a diagnosis and recommending alternative pharmacotherapy. Allergological diagnosis (skin, provocation) can be performed after gathering allergological and pharmachological history. Allergological examination is often required to confirm allergic nature of drug hypersensitivity reactions relative to antibiotics, NSAIDs, and anesthetics.

Skin tests. Skin testing is an available method for hypersensitivity reaction diagnosis [92, 101]. However, information about the development of standard diagnostic allergens on the basis of medications has not been found (at least in Russia). Prick testing and intradermal tests are especially important to identify lgErelated mechanisms of drug allergy [100]. Prick-tests are recommended for primary screening examination [102]. Intradermal testing can be performed in case of negative prick test findings, they are informative enough in case of immediate hypersensitivity reactions to beta-lactam antibiotics, heparin, and sometimes in delayed reactions as well. To determine the possibility of $T$ cell-mediated drug hypersensitivity delayed reactions, patch testing (application skin tests) and/or intradermal tests are performed [103-105]. In some cases negative results of skin testing can be explained by the fact, that it is not the medication but its metabolites possess immunogenic properties. In such situations drug provoking tests can be used to confirm the diagnosis.

Drug provocation test is the golden standard for identification of the drug having caused the development of hypersensitivity reactions [106]. Provocation tests with a drug which is supposed to cause the side-effect can confirm or exclude the diagnosis of drug hypersensitivity reaction. Such tests can be done as early as 1 month after the primary drug allergic reaction by a specially trained personnel in specialized centers having an experience in early identification of hypersensitivity 
reactions, and capable of rendering an adequate aid in case of life-threatening conditions [107].

Contraindication to provocation tests is availability of life-threatening drug hypersensitivity reaction (anaphylactic shock, other systemic reactions such as Stevens-Johnson syndrome, toxic epidermal necrolysis, vasculitis).

The route of introducing the suspected medication in provocation tests is mainly the same as in its initial application. But preference is given to peroral route, as it is connected with a lower risk of drug hypersensitivity reaction development [108].

Biological in vitro tests. The development of biological methods of diagnosing drug hypersensitivity reactions is believed to be a very promising direction [109]. Such methods are advantageous for the patients receiving multi-drug therapy and in heavy hypersensitivity reactions, when in vivo tests with medications are contraindicated. This kind of examinations is safe for the patient and is possible to be performed at the peak of clinical manifestations.

Among in vitro tests the majority of methods implemented into clinical practice are based on measurement of allergen-specific IgE antibodies to drug allergens. However, drug hypersensitivity IgE-related reactions seem to be less common than delayed hypersensitivity reactions ( $T$ lymphocytes-mediated) [93]. Besides, commercial kits for identifying specific IgE are available for a limited number of medications including amoxicillin, ampicillin, cephaclor, penicillin, insulin (bovine, porcine, human), adrenocorticotropic hormone, suxamethonium and some other preparations $[93,110]$. Absence of specific $\lg \mathrm{E}$ to the examined medications (negative test results) does not mean that immediate-type of drug allergy may be completely rejected in this case.

Determination of the level of $\lg E$ or $\lg G$ specific to medicaments may be justified in cases of medicationinduced cytopenia, hypersensitivity reactions to vaccines or dextrans. The sensitivity of these tests remains unexplored, and they are seldom used in diagnosic purposes [111].

Among other (not $\lg \mathrm{E}$ ) in vitro diagnostic methods the following tests for detection of mediators, released from various effector cells involved in the pathogenesis of drug hypersensitivity are used:

identifying cystenyl leukotriens, produced in vitro by isolated peripheral blood leukocytes after stimulation by drug allergen [112];

determining the level of histamine, tryptase, granzyme in blood serum, released from basophils and mast cells in acute drug allergic reactions, including anaphylaxia [113];

detecting cytokines released by lymphocytes.

At present, the possibility of drug hypersensitivity diagnosis using methods based on the cells participating in the immune response, is being studied. Examples of these methods are given below.

Test for release of histamine from basophils with fluorometric measurement is supposed to be rather promising and is now studied for revealing hypersensitivity reactions to certain drugs [114-116].

Basophil activation test is also one of the tests used for diagnosis of drug allergy. Basophils with high affinity of their receptors to $\mathrm{lgE}$ are used in this test as indicator cells. Basophils, activated by allergens in the presence of allergen-specific lgE, express markers of activation, such as CD63 and CD203c, and intracellular markers on their membranes. Such alterations in basophils can be detected by flow cytometry method using specific monoclonal antibodies to activation markers. Donor's basophils, patient's serum with a supposed drug allergy and a causative antigen are used in this diagnostic procedure [117].

Reactions of lymphocyte blast-transformation with various drug allergens and some other methods are also being used for diagnostic purposes.

Immunologic laboratory methods, listed above, such as test for release of histamine from basophils (under the influence of the diagnosed medication), basophil activation test, cysteine leukotrienes release test, lymphocyte activation test, reactions of lymphocyte blast-transformation may be in some separate cases rather useful, but at present they are not used in routine clinical practice, as they are not standardized for drug allergy diagnosis [93]. Informativity of many of them has not been convincingly proved and further investigations require substantial financial expenditure.

It should be underlined, that to confirm or exclude completely presence of hypersensitivity to various medications using only in vitro tests is impossible today. Test results must be interpreted in combination with medical history and clinical examination data [93].

The last achievements in the field of genetics revealed a number of HLA-allels, connected with forming hypersensitivity drug reactions, affecting mainly the skin. For example, the associations found between hypersensitivity to abacavir and HLA-B ${ }^{\star} 57: 01$ and between carbamazepine-induced Stevens-Johnson syndrome and $H L A-B^{*} 15: 02$ are realized in clinical practice - test-systems are developed for identification of susceptible people, which help to prevent drug allergy to carbamazepines restricting their application [42].

\section{Conclusion}

Hypersensitivity immune reactions to medications, according to the present concepts, are divided into immediate reactions (within 1-6 $\mathrm{h}$ after starting the preparation manifesting with various forms - from mild to life-threatening symptoms of anaphylaxia), or delayed reactions (several hours to several days after the offending medication is started, manifesting clinically with exanthemas in the majority of cases). Specific diagnosis of drug allergy is performed using in vivo tests (prick tests, intradermal tests, patch tests, provocation tests) and in vitro test (identification of drug specific IgE test, basophil activation tests, leukocyte blast-transformation reactions, quantitative identification 
of cytokines and other proteins, e.g. granzyme and tryptase in the peripheral blood). However, at present not all these methods are accessible in real clinical practice, the list of commercial kits for drug allergy diagnosis is limited. It is especially important in patient managing to rely on history-taking and general clinical examination data, to consider the available information on association of drug allergy and infections by viruses of herpes group, especially in children population, on hereditary predisposition to forming some kinds of drug allergy.

Study Funding and Conflicts of Interest. The work was not supported by any sources and there is no conflicts of interest related to it.

\section{References}

1. Demoly P., Adkinson N.F., Brockow K., Castells M., Chiriac A.M., Greenberger P.A., Khan D.A., Lang D.M., Park H.S., Pichler W., Sanchez-Borges M., Shiohara T., Thong B.Y. International Consensus on drug allergy. Allergy 2014; 69(4): 420-437, http://dx.doi.org/10.1111/all.12350.

2. Gomes E., Cardoso M.F., Praca F., Gomes L., Marino E., Demoly P. Self-reported drug allergy in a general adult Portuguese population. Clin Exp Allergy 2004; 34(10): 15971601, http://dx.doi.org/10.1111/j.1365-2222.2004.02070.x.

3. Dao R.-L., Su S.-C., Chung W.-H. Recent advances of pharmacogenomics in severe cutaneous adverse reactions: immune and nonimmune mechanisms. Asia Pac Allergy 2015; 5(2): 59-67, http://dx.doi.org/10.5415/apallergy.2015.5.2.59.

4. Balabolkin I.I., Bulgakova V.A. Klinicheskaya allergologiya detskogo vozrasta $s$ neotlozhnymi sostoyaniyami [Clinical allergology of childhood with urgent conditions]. Moscow: MIA; 2011; 264 p.

5. Rawlins M.D., Thompson J.W. Mechanisms of adverse drug reactions. In: Textbook of adverse drug reactions. Davies D.M. (editor). Oxford: Oxford University Press; 1991; p. $18-45$.

6. Doña I., Barrionuevo E., Blanca-Lopez N., Torres M.J., Fernandez T.D., Mayorga C., Canto G., Blanca M. Trends in hypersensitivity drug reactions: more drugs, more response patterns, more heterogeneity. J Investig Allergol Clin Immunol 2014; 24(3): 143-153.

7. Smyth R.M.D., Gargon E., Kirkham J., Cresswell L., Golder S., Smyth R., Williamson P. Adverse drug reactions in children - a systematic review. PLoS One 2012; 7(3): e24061, http://dx.doi.org/10.1371/journal.pone.0024061.

8. Ponvert C., Scheinmann P. Allergic and pseudoallergic reactions to analgesics, antipyretics and non-steroidal antiinflammatory drugs. Arch Pediatr 2007; 14(5): 507-512, http:// dx.doi.org/10.1016/j.arcped.2007.03.009.

9. Ayuso P., Blanca-López N., Doña I., Torres M.J., Guéant-Rodríguez R.M., Canto G., Sanak M., Mayorga C., Guéant J.L., Blanca M., Cornejo-García J.A. Advanced phenotyping in hypersensitivity drug reactions to NSAIDs. Clin Exp Allergy 2013; 43(10): 1097-1109, http://dx.doi.org/10.1111/ cea.12140.

10. Farnam K., Chang C., Teuber S., Gershwin M.E. Nonallergic drug hypersensitivity reactions. Int Arch Allergy Immunol 2012; 159(4): 327-345, http://dx.doi. org/10.1159/000339690.

11. Newmark J.L., Mehra A., Singla A.K. Radiocontrast media allergic reactions and interventional pain practice - a review. Pain Physician 2012; 15(5): E665-E675.

12. Grigiene G., Norkūnienè J., Kvedariene V. The time delay between drug intake and bronchospasm for nonsteroidal antiinflammatory drugs sensitive patients. World Allergy Organ J 2010; 3(12): 266-270, http://dx.doi.org/10.1097/ wox.0b013e3181fdfc5f.

13. Stone S.F., Phillips E.J., Wiese M.D., Heddle R.J., Brown S.G. Immediate-type hypersensitivity drug reactions. $\mathrm{Br}$ J Clin Pharmacol 2014; 78(1): 1-13, http://dx.doi.org/10.1111/ bcp.12297.

14. Erkoçoğlu M., Kaya A., Civelek E., Ozcan C., Cakır B., Akan A., Toyran M., Ginis T., Kocabas C.N. Prevalence of confirmed immediate type drug hypersensitivity reactions among school children. Pediatr Allergy Immunol 2013; 24(2): 160-167, http://dx.doi.org/10.1111/pai.12047.

15. Schrijvers R., Gilissen L., Chiriac A.M., Demoly P. Pathogenesis and diagnosis of delayed-type drug hypersensitivity reactions, from bedside to bench and back. Clin Transl Allergy 2015; 5: 31, http://dx.doi.org/10.1186/s13601015-0073-8.

16. Yazıcıoğlu M. Approach to drug allergies in the childhood. Turk Pediatri Ars 2014; 49(2): 99-103, http://dx.doi. org/10.5152/tpa.2014.1944.

17. Blanca M., Romano A., Torres M.J., Férnandez J., Mayorga C., Rodriguez J., Demoly P., Bousquet P.J., Merk H.F., Sanz M.L., Ott H., Atanasković-Marković M. Update on the evaluation of hypersensitivity reactions to betalactams. Allergy 2009; 64(2): 183-193, http://dx.doi.org/10.1111/j.13989995.2008.01916.x.

18. Bircher A.J., Scherer Hofmeier K. Drug hypersensitivity reactions: Inconsistency in the use of the classification of immediate and nonimmediate reactions. J Allergy Clin Immunol 2012; 129(1): 263-264, http://dx.doi.org/10.1016/ j.jaci.2011.08.042.

19. Pichler W.J., Adam J., Daubner B., Gentinetta T., Keller M., Yerly D. Drug hypersensitivity reactions: pathomechanism and clinical symptoms. Med Clin North Am 2010; 94(4): 645-664, http://dx.doi.org/10.1016/j.mcna.2010. 04.003.

20. Gómez E., Torres M.J., Mayorga C., Blanca M. Immunologic evaluation of drug allergy. Allergy Asthma Immunol Res 2012; 4(5): 251-263, http://dx.doi.org/10.4168/ aair.2012.4.5.251.

21. Gell P.G.H., Coombs R.R.A. The classification of allergic reactions underlying disease. In: Clinical aspects of immunology. Coombs R.R.A., Gell P.G.H. (editors). London, UK: Blackwell Sci; 1963; p. 317-337.

22. Pichler W.J. Delayed drug hypersensitivity reactions. Ann Intern Med 2003; 139(8): 683-693, http://dx.doi. org/10.7326/0003-4819-139-8-200310210-00012.

23. Park B.K., Naisbitt D.J., Demoly P. Drug hypersensitivity. In: Allergy. New York: Elsevier BV; 2012; p. 321-330, http:// dx.doi.org/10.1016/b978-0-7234-3658-4.00020-2.

24. Macy E. Practical management of patients with a history of immediate hypersensitivity to common non-beta-lactam drugs. Curr Allergy Asthma Rep 2016; 16(1): 4, http://dx.doi. org/10.1007/s11882-015-0584-3.

25. Limsuwan T., Demoly P. Acute symptoms of drug hypersensitivity (urticaria, angioedema, anaphylaxis, anaphylactic shock). Med Clin North Am 2010; 94(4): 691-710, http://dx.doi.org/10.1016/j.mcna.2010.03.007.

26. Eliseeva T.I. Neotlozhnaya allergologiya. $\mathrm{V} \mathrm{kn}$.: 
Neotlozhnye sostoyaniya $v$ pediatrii [Urgent allergology. In: Urgent conditions in pediatrics]. Pod red. Prakhova A.V. [Prakhov A.V. (editor)]. Nizhny Novgorod: Izdatel'stvo NGMA; 2005; p. 191-213.

27. Leach M.W., Rottman J.B., Hock M.B., Finco D., Rojko J.L., Beyer J.C. Immunogenicity/hypersensitivity of biologics. Toxicol Pathol 2014; 42(1): 293-300, http://dx.doi. org/10.1177/0192623313510987.

28. Garratty G. Immune hemolytic anemia caused by drugs. Expert Opin Drug Saf 2012; 11(4): 635-642, http://dx.doi.org/10. 1517/14740338.2012.678832.

29. Rojko J.L., Evans M.G., Price S.A., Han B., Waine G., DeWitte M., Haynes J., Freimark B., Martin P., Raymond J.T., Evering W., Rebelatto M.C., Schenck E., Horvath C. Formation, clearance, deposition, pathogenicity, and identification of biopharmaceutical-related immune complexes: review and case studies. Toxicol Pathol 2014; 42(4): 725-764, http://dx.doi.org/1 $0.1177 / 0192623314526475$.

30. Clark B.M., Kotti G.H., Shah A.D., Conger N.G. Severe serum sickness reaction to oral and intramuscular penicillin. Pharmacotherapy 2006; 26(5): 705-708, http://dx.doi. org/10.1592/phco.26.5.705.

31. Koransky R., Ferastraoaru D., Jerschow E. Single nonsteroidal anti-inflammatory drug induced serum sicknesslike reaction to naproxen in a patient able to tolerate both aspirin and ibuprofen. J Allergy Clin Immunol Pract 2016; 4(1): 160161, http://dx.doi.org/10.1016/j.jaip.2015.07.019.

32. Hanai S., Sato T., Takeda K., Nagatani K., Iwamoto M., Minota S. Drug-induced lupus caused by long term minocycline treatment for acne vulgaris. Arerugi 2015; 64(9): 1269-1273, http://dx.doi.org/10.15036/arerugi.64.1269.

33. Mockenhaupt M. Severe drug-induced skin reactions: clinical pattern, diagnostics and therapy. J Dtsch Dermatol Ges 2009; 7(2): 142-160, http://dx.doi.org/10.1111/j.16100387.2008.06878.x.

34. Bircher A.J., Scherer K. Delayed cutaneous manifestations of drug hypersensitivity. Med Clin North Am 2010; 94(4): 711-725, http://dx.doi.org/10.1016/ j.mcna.2010.04.001.

35. Ghane Shahrbaf F., Assadi F. Drug-induced renal disorders. J Renal Inj Prev 2015; 4(3): 57-60, http://dx.doi. org/10.12861/jrip.2015.12.

36. Schwaiblmair M., Behr W., Haeckel T., Märkl B., Foerg W., Berghaus T. Drug induced interstitial lung disease. Open Respir Med J 2012; 6: 63-74, http://dx.doi.org/10.2174/1 874306401206010063.

37. Jacquier J., Chik C.L., Senior P.A. A practical, clinical approach to the assessment and management of suspected insulin allergy. Diabet Med 2013; 30(8): 977-985, http://dx.doi. org/10.1111/dme.12194.

38. Hoffman A.G., Schram S.E., Ercan-Fang N.G., Warshaw E.M. Type I allergy to insulin: case report and review of localized and systemic reactions to insulin. Dermatitis 2008; 19(1): 52-58.

39. Kim D., Baraniuk J. Delayed-type hypersensitivity reaction to the meta-cresol component of insulin. Ann Allergy Asthma Immunol 2007; 99(2): 194-195, http://dx.doi. org/10.1016/S1081-1206(10)60645-X.

40. Faulkner L., Meng X., Park B.K., Naisbitt D.J. The importance of hapten-protein complex formation in the development of drug allergy. Curr Opin Allergy Clin Immunol 2014; 14(4): 293-300, http://dx.doi.org/10.1097/ $\mathrm{ACl} .0000000000000078$.
41. Oussalah A., Mayorga C., Blanca M., Barbaud A., Nakonechna A., Cernadas J., Gotua M., Brockow K., Caubet J.C., Bircher A., Atanaskovic M., Demoly P., KaseTanno L., Terreehorst I., Laguna J.J., Romano A., Guéant J.L.; Task force "Genetic predictors of drug hypersensitivity" of the European Network on Drug Allergy (ENDA) of EAACl. Genetic variants associated with drugs-induced immediate hypersensitivity reactions: a PRISMA-compliant systematic review. Allergy 2015, http://dx.doi.org/10.1111/all.12821. [Epub ahead of print].

42. Pirmohamed M., Ostrov D.A., Park B.K. New genetic findings lead the way to a better understanding of fundamental mechanisms of drug hypersensitivity. J Allergy Clin Immunol 2015; 136(2): 236-244, http://dx.doi.org/10.1016/ j.jaci.2015.06.022.

43. Chung W.H., Hung S.I., Hong H.S., Hsih M.S., Yang L.C., Ho H.C., Wu J.Y., Chen Y.T. Medical genetics: a marker for Stevens-Johnson syndrome. Nature 2004; 428(6982): 486, http://dx.doi.org/10.1038/428486a.

44. Guglielmi L., Fontaine C., Gougat C., Avinens O., Eliaou J.F., Guglielmi P., Demoly P. IL-10 promoter and IL4Ralpha gene SNPs are associated with immediate beta-lactam allergy in atopic women. Allergy 2006; 61(8): 921-927, http:// dx.doi.org/10.1111/j.1398-9995.2006.01067.x.

45. Caubet J.C., Kaiser L., Lemaître B., Fellay B., Gervaix A., Eigenmann P.A. The role of penicillin in benign skin rashes in childhood: a prospective study based on drug rechallenge. J Allergy Clin Immunol 2011; 127(1): 218-222, http://dx.doi.org/10.1016/j.jaci.2010.08.025.

46. Hubiche T., Milpied B., Cazeau C., Taïeb A., LéautéLabrèze C. Association of immunologically confirmed delayed drug reaction and human herpesvirus 6 viremia in a pediatric case of drug-induced hypersensitivity syndrome. Dermatology 2011; 222(2): 140-141, http://dx.doi.org/10.1159/000324506.

47. Özcan D., Seçkin D., Bilezikçi B., Arslan H. The role of human herpesvirus-6, Epstein-Barr virus and cytomegalovirus infections in the etiopathogenesis of different types of cutaneous drug reactions. Int J Dermatol 2010; 49(11): 1250-1254, http:// dx.doi.org/10.1111/j.1365-4632.2010.04531.x.

48. Camous X., Calbo S., Picard D., Musette P. Drug reaction with eosinophilia and systemic symptoms: an update on pathogenesis. Curr Opin Immunol 2012; 24(6): 730-735, http://dx.doi.org/10.1016/j.coi.2012.07.010.

49. Balabolkin I.I. Drug allergy in children: clinical and pathogenetic types, diagnosis and prevention. Rossiyskiy pediatricheskiy zhurnal 2011; 1: 49-53.

50. Ferrusquía J., Pérez-Martínez I., Gómez de la Torre R., Fernández-Almira M.L., de Francisco R., Rodrigo L., Riestra S. Gastroenterology case report of mesalazine-induced cardiopulmonary hypersensitivity. World J Gastroenterol 2015; 21(13): 4069-4077, http://dx.doi.org/10.3748/wjg.v21.i13.4069.

51. Rossiyskaya assotsiatsiya allergologov i klinicheskikh immunologov. Federal'nye klinicheskie rekomendatsii po diagnostike $i$ lecheniyu lekarstvennoy allergii [Russian Association of Allergology and Clinical Immunology. Federal guidelines for the diagnosis and treatment of drug allergy]. Moscow; 2014.

52. Marzano A.V., Borghi A., Cugno M. Adverse drug reactions and organ damage: the skin. Eur J Intern Med 2016; 28: 17-24, http://dx.doi.org/10.1016/j.ejim.2015.11.017.

53. Uetrecht J., Naisbitt D.J. Idiosyncratic adverse drug reactions: current concepts. Pharmacol Rev 2013; 65(2): 779808, http://dx.doi.org/10.1124/pr.113.007450. 
54. Żukiewicz-Sobczak W.A., Wróblewska P., Adamczuk P., Zwoliński J., Oniszczuk A., Wojtyła-Buciora P., Silny W. Drugs as important factors causing allergies. Postepy Dermatol Alergol 2015; 32(5): 388-392, http://dx.doi.org/10.5114/ pdia.2014.44021.

55. Valeyrie-Allanore L., Sassolas B., Roujeau J.C. Druginduced skin, nail and hair disorders. Drug Saf 2007; 30(11): 1011-1030, http://dx.doi.org/10.2165/00002018-20073011000003.

56. Segal A.R., Doherty K.M., Leggott J., Zlotoff B. Cutaneous reactions to drugs in children. Pediatrics 2007; 120(4): e1082-e1096, http://dx.doi.org/10.1542/peds.20052321.

57. Kowalski M.L., Woessner K., Sanak M. Approaches to the diagnosis and management of patients with a history of nonsteroidal anti-inflammatory drug-related urticaria and angioedema. J Allergy Clin Immunol 2015; 136(2): 245-251, http://dx.doi.org/10.1016/j.jaci.2015.06.021.

58. Rossiyskaya assotsiatsiya allergologov i klinicheskikh immunologov. Federal'nye klinicheskie rekomendatsii po diagnostike $i$ lecheniyu krapivnitsy [Russian Association of Allergology and Clinical Immunology. Federal guidelines for the diagnosis and treatment of urticaria]. Moscow; 2013.

59. Flowers H., Brodell R., Brents M., Wyatt J.P. Fixed drug eruptions: presentation, diagnosis, and management. South Med J 2014; 107(11): 724-727, http://dx.doi.org/10.14423/ SMJ.0000000000000195.

60. Shiohara T. Fixed drug eruption: pathogenesis and diagnostic tests. Curr Opin Allergy Clin Immunol 2009; 9(4): 316-321, http://dx.doi.org/10.1097/ACl.0b013e32832cda4c.

61. Sidoroff A., Halevy S., Bavinck J.N., Vaillant L., Roujeau J.C. Acute generalized exanthematous pustulosis (AGEP) - a clinical reaction pattern. J Cutan Pathol 2001; 28(3): 113-119, http://dx.doi.org/10.1034/j.16000560.2001.028003113.x.

62. Pavlos R., Mallal S., Phillips E. HLA and pharmacogenetics of drug hypersensitivity. Pharmacogenomics 2012; 13(11): 1285-1306, http://dx.doi.org/10.2217/pgs.12.108.

63. Shear N.H., Spielberg S.P. Anticonvulsant hypersensitivity syndrome. In vitro assessment of risk. J Clin Invest 1988; 82(6): 1826-1832, http://dx.doi.org/10.1172/ JCl113798.

64. Walsh S.A., Creamer D. Drug reaction with eosinophilia and systemic symptoms (DRESS): a clinical update and review of current thinking. Clin Exp Dermatol 2011; 36(1): 6-11, http:// dx.doi.org/10.1111/j.1365-2230.2010.03967.x.

65. Cacoub P., Musette P., Descamps V., Meyer O., Speirs C., Finzi L., Roujeau J.C. The DRESS syndrome: a literature review. Am J Med 2011; 124(7): 588-597, http:// dx.doi.org/10.1016/j.amjmed.2011.01.017.

66. Picard D., Janela B., Descamps V., D'Incan M., Courville P., Jacquot S., Rogez S., Mardivirin L., MoinsTeisserenc H., Toubert A., Benichou J., Joly P., Musette P. Drug reaction with eosinophilia and systemic symptoms (DRESS): a multiorgan antiviral T cell response. Sci Transl Med 2010; 2(46): 46-62, http://dx.doi.org/10.1126/scitransImed.3001116.

67. Lamoreux M.R., Sternbach M.R., Hsu W.T. Erythema multiforme. Am Fam Physician 2006; 74(11): 1883-1888.

68. Eun L.Y., Go J.W., Kang W.H., Kim S.H., Cho H.K. Erythema multiforme associated with Kawasaki Disease in a Korean child. Eur J Dermatol 2010; 20(4): 524-525, http:// dx.doi.org/10.1684/ejd.2010.0972.

69. Beckwith $H$. Erythema multiforme: a simple rash or sinister sign? BMJ Case Rep 2012; 2012: bcr1120115072, http://dx.doi.org/10.1136/bcr.11.2011.5072.

70. Ministerstvo zdravookhraneniya Rossiyskoy Federatsii. Soyuz pediatrov Rossii. Federal'nye klinicheskie rekomendatsii po okazaniyu meditsinskoy pomoshchi detyam s mnogoformnoy ekssudativnoy eritemoy $i$ toksikodermiey [Ministry of Health of the Russian Federation. Union of Pediatricians of Russia. Federal guidelines for the provision of medical care for children with erythema multiforme and toxicodermie]. Moscow; 2015.

71. Chang Y.S., Huang F.C., Tseng S.H., Hsu C.K., Ho C.L., Sheu H.M. Erythema multiforme, Stevens-Johnson syndrome, and toxic epidermal necrolysis: acute ocular manifestations, causes, and management. Cornea 2007; 26(2): 123-129, http:// dx.doi.org/10.1097/ico.0b013e31802eb264.

72. Łoboda J., Dudzik A., Chomyszyn-Gajewska M. Stevens-Johnson syndrom and toxic epidermal necrolysis based on literature. Przegl Lek 2015; 72(1): 35-37.

73. Wheatley L.M., Plaut M., Schwaninger J.M., Banerji A., Castells M., Finkelman F.D., Gleich G.J., GuttmanYassky E., Mallal S.A., Naisbitt D.J., Ostrov D.A., Phillips E.J., Pichler W.J., Platts-Mills T.A., Roujeau J.C., Schwartz L.B., Trepanier L.A. Report from the National Institute of Allergy and Infectious Diseases workshop on drug allergy. J Allergy Clin Immunol 2015; 136(2): 262-271.e2, http://dx.doi.org/10.1016/ j.jaci.2015.05.027.

74. Harr T., French L.E. Toxic epidermal necrolysis and Stevens-Johnson syndrome. Orphanet J Rare Dis 2010; 5: 39, http://dx.doi.org/10.1186/1750-1172-5-39.

75. Roujeau J.C. Clinical heterogeneity of drug hypersensitivity. Toxicology 2005; 209(2): 123-129, http:// dx.doi.org/10.1016/j.tox.2004.12.022.

76. Wei C.Y., Chung W.H., Huang H.W., Chen Y.T., Hung S.I. Direct interaction between HLA-B and carbamazepine activates $\mathrm{T}$ cells in patients with Stevens-Johnson syndrome. J Allergy Clin Immunol 2012; 129(6): 1562-1569.e5, http:// dx.doi.org/10.1016/j.jaci.2011.12.990.

77. Chung W.H., Hung S.I., Yang J.Y., Su S.C., Huang S.P., Wei C.Y., Chin S.W., Chiou C.C., Chu S.C., Ho H.C., Yang C.H., Lu C.F., Wu J.Y., Liao Y.D., Chen Y.T. Granulysin is a key mediator for disseminated keratinocyte death in StevensJohnson syndrome and toxic epidermal necrolysis. Nat Med 2008; 14(12): 1343-1350, http://dx.doi.org/10.1038/nm.1884.

78. de Araujo E., Dessirier V., Laprée G., ValeyrieAllanore L., Ortonne N., Stathopoulos E.N., Bagot M., Bensussan A., Mockenhaupt M., Roujeau J.C., Tsapis A. Death ligand TRAIL, secreted by CD1a+ and CD14+ cells in blister fluids, is involved in killing keratinocytes in toxic epidermal necrolysis. Exp Dermatol 2011; 20(2): 107-112, http://dx.doi. org/10.1111/j.1600-0625.2010.01176.x.

79. Abe R., Yoshioka N., Murata J., Fujita Y., Shimizu H. Granulysin as a marker for early diagnosis of the StevensJohnson syndrome. Ann Intern Med 2009; 151(7): 514-515, http://dx.doi.org/10.7326/0003-4819-151-7-200910060-00016.

80. Rodríguez-Pazos L., Gómez-Bernal S., RodríguezGranados M.T., Toribio J. Photodistributed erythema multiforme. Actas Dermosifiliogr 2013; 104(8): 645-653, http://dx.doi. org/10.1016/j.adengl.2012.01.024.

81. Rossiyskaya assotsiatsiya allergologov i klinicheskikh immunologov. Federal'nye klinicheskie rekomendatsii po anafilakticheskomu shoku [Russian Association of Allergology and Clinical Immunology. Federal guidelines for the anaphylactic shock]. Moscow; 2013.

82. Simons F.E., Ardusso L.R., Bilò M.B., Cardona V., 
Ebisawa M., El-Gamal Y.M., Lieberman P., Lockey R.F., Muraro A., Roberts G., Sanchez-Borges M., Sheikh A., Shek L.P., Wallace D.V., Worm M. International consensus on (ICON) anaphylaxis. World Allergy Organ J 2014; 7(1): 9, http:// dx.doi.org/10.1186/1939-4551-7-9.

83. Simons F.E., Ebisawa M., Sanchez-Borges M., Thong B.Y., Worm M., Tanno L.K., Lockey R.F., El-Gamal Y.M., Brown S.G., Park H.S., Sheikh A. 2015 update of the evidence base: World Allergy Organization anaphylaxis guidelines. World Allergy Organ J 2015; 8(1): 32, http://dx.doi.org/10.1186/ s40413-015-0080-1.

84. Mori F., Fili L., Barni S., Sarti L., Pucci N., Parronchi P., Novembre E. Drug fever after a single dose of amoxicillinclavulanic acid. J Allergy Clin Immunol Pract 2015, http://dx.doi. org/10.1016/j.jaip.2015.11.030. [Epub ahead of print].

85. Patel R.A., Gallagher J.C. Drug fever. Pharmacotherapy 2010; 30(1): 57-69, http://dx.doi.org/10.1592/phco.30.1.57.

86. Gomes E.R., Brockow K., Kuyucu S., Saretta F., Mori F., Blanca-Lopez N., Ott H., Atanaskovic-Markovic M., Kidon M., Caubet J.C., Terreehorst I.; ENDA/EAACl Drug Allergy Interest Group. Drug hypersensitivity in children: report from the pediatric task force of the EAACI Drug Allergy Interest Group. Allergy 2016; 71(2): 149-161, http://dx.doi.org/10.1111/ all.12774.

87. Shiohara T., Kano Y. A complex interaction between drug allergy and viral infection. Clin Rev Allergy Immunol 2007; 33(1): 124-133, http://dx.doi.org/10.1007/s12016-007-8010-9.

88. Chovel-Sella A., Ben Tov A., Lahav E., Mor O., Rudich H., Paret G., Reif S. Incidence of rash after amoxicillin treatment in children with infectious mononucleosis. Pediatrics 2013; 131(5): e1424-e1427, http://dx.doi.org/10.1542/ peds.2012-1575.

89. Leuppi J.D., Schnyder P., Hartmann K., Reinhart W.H., Kuhn M. Drug-induced bronchospasm: analysis of 187 spontaneously reported cases. Respiration 2001; 68(4): 345-351, http://dx.doi.org/10.1159/000050525.

90. Hompes S., Köhli A., Nemat K., Scherer K., Lange L., Rueff F., Rietschel E., Reese T., Szepfalusi Z., Schwerk N., Beyer K., Hawranek T., Niggemann B., Worm M. Provoking allergens and treatment of anaphylaxis in children and adolescents - data from the anaphylaxis registry of Germanspeaking countries. Pediatr Allergy Immunol 2011; 22(6): 568574, http://dx.doi.org/10.1111/j.1399-3038.2011.01154.x.

91. Levi N., Bastuji-Garin S., Mockenhaupt M., Roujeau J.C., Flahault A., Kelly J.P., Martin E., Kaufman D.W., Maison P. Medications as risk factors of Stevens-Johnson syndrome and toxic epidermal necrolysis in children: a pooled analysis. Pediatrics 2009; 123(2): e297-e304, http://dx.doi.org/10.1542/ peds.2008-1923.

92. Rive C.M., Bourke J., Phillips E.J. Testing for drug hypersensitivity syndromes. Clin Biochem Rev 2013; 34(1): 15-38.

93. Brockow K., Przybilla B., Aberer W., Bircher A.J., Brehler R., Dickel H., Fuchs T., Jakob T., Lange L., Pfützner W., Mockenhaupt M., Ott H., Pfaar O., Ring J., Sachs B., Sitter H., Trautmann A., Treudler R., Wedi B., Worm M., Wurpts G., Zuberbier T., Merk H.F. Guideline for the diagnosis of drug hypersensitivity reactions. Allergo J Int 2015; 24(3): 94-105, http://dx.doi.org/10.1007/s40629-015-0052-6.

94. Chiriac A.M., Demoly P. Multiple drug hypersensitivity syndrome. Curr Opin Allergy Clin Immunol 2013; 13(4): 323329, http://dx.doi.org/10.1097/aci.0b013e3283630c36.

95. Neukomm C.B., Yawalkar N., Helbling A., Pichler W.J. T cell reactions to drugs in distinct clinical manifestations of drug allergy. J Investig Allergol Clin Immunol 2001; 11(4): 275-284.

96. Macy E., Ho N.J. Multiple drug intolerance syndrome: prevalence, clinical characteristics, and management. Ann Allergy Asthma Immunol 2012; 108(2): 88-93, http://dx.doi. org/10.1016/j.anai.2011.11.006.

97. Asero R. Multiple drug allergy syndrome: a distinct clinical entity. Curr Allergy Rep 2001; 1(1): 18-22, http://dx.doi. org/10.1007/s11882-001-0092-5.

98. Omer H.M., Hodson J., Thomas S.K., Coleman J.J. Multiple drug intolerance syndrome: a large-scale retrospective study. Drug Saf 2014; 37(12): 1037-1045, http://dx.doi. org/10.1007/s40264-014-0236-X.

99. Hari Y., Frutig-Schnyder K., Hurni M., Yawalkar N., Zanni M.P., Schnyder B., Kappeler A., von Greyerz S., Braathen L.R., Pichler W.J. T cell involvement in cutaneous drug eruptions. Clin Exp Allergy 2001; 31(9): 1398-1408, http:// dx.doi.org/10.1046/j.1365-2222.2001.01164.x.

100. Bircher A.J. Symptoms and danger signs in acute drug hypersensitivity. Toxicology 2005; 209(2): 201-207, http:// dx.doi.org/10.1016/j.tox.2004.12.036.

101. Lee A.Y., Chey W.Y., Choi J., Jeon J.S. Insulin-induced drug eruptions and reliability of skin tests. Acta Derm Venereol 2002; 82(2): 114-117, http://dx.doi.org/10.1080/000155502529 48149.

102. Kränke B., Aberer W. Skin testing for IgE-mediated drug allergy. Immunol Allergy Clin North Am 2009; 29(3): 503516, http://dx.doi.org/10.1016/j.iac.2009.04.003.

103. Brockow K., Garvey L.H., Aberer W., AtanaskovicMarkovic M., Barbaud A., Bilo M.B., Bircher A., Blanca M., Bonadonna B., Campi P., Castro E., Cernadas J.R., Chiriac A.M., Demoly P., Grosber M., Gooi J., Lombardo C., Mertes P.M., Mosbech H., Nasser S., Pagani M., Ring J., Romano A., Scherer K., Schnyder B., Testi S., Torres M., Trautmann A., Terreehorst I.; ENDA/EAACI Drug Allergy Interest Group. Skin test concentrations for systemically administered drugs - an ENDA/EAACI Drug Allergy Interest Group position paper. Allergy 2013; 68(6): 702-712, http://dx.doi.org/10.1111/ all.12142.

104. Barbaud A. Drug patch testing in systemic cutaneous drug allergy. Toxicology 2005; 209(2): 209-216, http://dx.doi. org/10.1016/j.tox.2004.12.024.

105. Santiago F., Gonçalo M., Vieira R., Coelho S., Figueiredo A. Epicutaneous patch testing in drug hypersensitivity syndrome (DRESS). Contact Dermatitis 2010; 62(1): 47-53, http://dx.doi.org/10.1111/j.1600-0536.2009.01659.x.

106. Rerkpattanapipat T., Chiriac A.M., Demoly P. Drug provocation tests in hypersensitivity drug reactions. Curr Opin Allergy Clin Immunol 2011; 11(4): 299-304, http://dx.doi. org/10.1097/ACl.0b013e328348a4e9.

107. Bousquet P.J., Gaeta F., Bousquet-Rouanet L., Lefrant J.Y., Demoly P., Romano A. Provocation tests in diagnosing drug hypersensitivity. Curr Pharm Des 2008; 14(27): 2792-2802, http://dx.doi.org/10.2174/13816120878636 9731.

108. Aberer W., Bircher A., Romano A., Blanca M., Campi P., Fernandez J., Brockow K., Pichler W.J., Demoly P.; European Network for Drug Allergy (ENDA); EAACl interest group on drug hypersensitivity. Drug provocation testing in the diagnosis of drug hypersensitivity reactions: general considerations. Allergy 2003; 58(9): 854-863, http://dx.doi. org/10.1034/j.1398-9995.2003.00279.x.

109. Mayorga C., Sanz M.L., Gamboa P., Garcia- 
Aviles M.C., Fernandez J., Torres M.J.; Spanish Society of Allergy and Clinical; Immunology; Immunology and Drug Allergy Committee. In vitro methods for diagnosing nonimmediate hypersensitivity reactions to drugs. J Investig Allergol Clin Immunol 2013; 23(4): 213-225.

110. Fontaine C., Mayorga C., Bousquet P.J., Arnoux B., Torres M.J., Blanca M., Demoly P. Relevance of the determination of serum-specific IgE antibodies in the diagnosis of immediate beta-lactam allergy. Allergy 2007; 62(1): 47-52, http://dx.doi.org/10.1111/j.1398-9995.2006.01268.x.

111. Demoly P., Lebel B., Messaad D., Sahla H., Rongier M., Daurès J.P., Godard P., Bousquet J. Predictive capacity of histamine release for the diagnosis of drug allergy. Allergy 1999; 54(5): 500-506, http://dx.doi.org/10.1034/j.1398-9995. 1999.00020.x.

112. Lebel B., Messaad D., Kvedariene V., Rongier M., Bousquet J., Demoly P. Cysteinyl-leukotriene release test (CAST) in the diagnosis of immediate drug reactions. Allergy 2001; 56(7): 688-692, http://dx.doi.org/10.1034/j.1398-9995.2001.00103.x.

113. Mirone C., Preziosi D., Mascheri A., Micarelli G., Farioli L., Balossi L.G., Scibilia J., Schroeder J., Losappio L.M., Aversano M.G., Stafylaraki C., Nichelatti M., Pastorello E.A. Identification of risk factors of severe hypersensitivity reactions in general anaesthesia. Clin Mol Allergy 2015; 13(1): 11, http:// dx.doi.org/10.1186/s12948-015-0017-9.

114. Kvedariene V., Kamey S., Ryckwaert Y., Rongier M., Bousquet J., Demoly P., Arnoux B. Diagnosis of neuromuscular blocking agent hypersensitivity reactions using cytofluorimetric analysis of basophils. Allergy 2006; 61(3): 311-315, http:// dx.doi.org/10.1111/j.1398-9995.2006.00978.x.

115. Leysen J., Sabato V., Verweij M.M., De Knop K.J., Bridts C.H., De Clerck L.S., Ebo D.G. The basophil activation test in the diagnosis of immediate drug hypersensitivity. Expert Rev Clin Immunol 2011; 7(3): 349-355, http://dx.doi. org/10.1586/eci.11.14.

116. Pineda F., Ariza A., Mayorga C., Arribas F., GonzálezMendiola R., Blanca-López N., Davila G., Cabañes N., Canto G., Laguna J.J., Senent C., Stahl-Skov P., Palacios R., Blanca M., Torres M.J. Role of histamine release test for the evaluation of patients with immediate hypersensitivity reactions to clavulanic acid. Int Arch Allergy Immunol 2016; 168(4): 233 240, http://dx.doi.org/10.1159/000443274.

117. Hausmann O.V., Gentinetta T., Bridts C.H., Ebo D.G. The basophil activation test in immediate-type drug allergy. Immunol Allergy Clin North Am 2009; 29(3): 555-566, http:// dx.doi.org/10.1016/j.iac.2009.04.011. 